\title{
THE INTRASPINAL TREATMENT OF SYPHILIS OF THE CENTRAL NERVOUS SYSTEM, ACCORDING TO THE METHOD OF SWIFT AND ELLIS*
}

\author{
RICHARD DEXTER, M.D., AND CLYDE L. CUMMER, M.D. \\ CLEVELAND
}

In 1912 Swift and Ellis ${ }^{1}$ described a method for the intraspinal treatment of syphilis of the cerebrospinal axis. They felt that since practically all drugs were excreted into the subarachnoid space either poorly or not at all, a direct application of salvarsan to the meninges would have a distinctly greater curative effect than when salvarsan was given only by the intravenous route. That intraspinal injections of salvarsan or neosalvarsan, dissolved in salt solution, were far too irritating to be practical was shown by their ${ }^{2}$ experiments on monkeys. The medium which Swift and Ellis ${ }^{1,3}$ finally decided on was the blood serum of a patient, withdrawn shortly after the intravenous administration of salvarsan. This blood serum, diluted with salt solution, was introduced into the subarachnoid space, without severe symptoms of meningeal irritation and with beneficial results in syphilis. This method has been criticized on the ground that it was unnecessary because the intravenous injection of salvarsan was all-sufficient in its action. In the light of the recent investigations of Adler, ${ }^{4} \mathrm{Hall},{ }^{5}$ Swift, ${ }^{6}$ Camp $^{7}$ and others, who have shown that no arsenic, or only the merest trace of it, appears in the spinal fluid after the intravenous administration of salvarsan, it would seem that the direct method is the only way in which arsenic can be introduced into the subarachnoid space in adequate dosage.

Another criticism has been that a therapeutically negligible amount of arsenic was introduced in the "autosalvarsanized" serum. Draper has shown that no more than 0.25 milligram to 0.5 milligram of salvarsan can be introduced repeatedly with safety into the subarachnoid space. Swift ${ }^{6}$ and Adler have shown that blood serum, removed a

* Submitted for publication Sept. 9, 1915.

1. Swift, H. F., and Ellis, A. W. M.: New York Med. Jour., July 13, 1912.

2. Ellis, A. W. M., and Swift, Homer F.: Jour. Exper. Med., 1913, xviii, 4.

3. Swift, Homer F., and Ellis, A. W. M.: The Archives Int. Med., 1913, xii, 331.

4. Adler, Herman M.: Boston Med. and Surg. Jour., 1914, clxxi, 900.

5. Hall, G. W.: Jour. Am. Med. Assn., April 24, 1915, lxiv, 1384.

6. Swift, H. F.: Jour. Am. Med. Assn., 1915, 1xv, 209.

7. Camp: Lancet-Clinic, 1915, cxiii, 116.

9. Draper, George: The ARchives Int. Med., 1915, xv, 16. 
short time after the intravenous administration of salvarsan, contains amounts varying between these limits, and seldom below them.

It would seem, then, that by the intraspinal injection of autosalvarsanized serum we have a method of introducing arsenic in nontoxic doses into the subarachnoid space. Several other methods for the introduction of neosalvarsan and salvarsan into the subarachnoid space have been described, notably that of Ravaut ${ }^{9}$ and Wile's ${ }^{10}$ modification of this method and that of Ogilvie. ${ }^{11}$ A discussion of these methods would be out of place in this paper as we have had no personal experience with them.

Since the communications of Swift and Ellis, numerous reports regarding the efficiency of autosalvarsanized serum in the treatment of syphilis of the central nervous system have appeared. A brief review of them is of considerable interest.

McCaskey ${ }^{12}$ gave twenty intraspinal injections to seven patients. His longest observation extended over a period of three months. $\mathrm{He}$ states that some of his patients improved very much under treatment. He gives no data as to the effect of the treatment on the laboratory findings. In another article ${ }^{13}$ the same author describes some technical modifications of the method, but fails to state whether or not his results were favorable.

Hough $^{14}$ treated six paretics. As two of his cases received but one treatment each, his report is based on his results in four cases. Three showed some symptomatic improvement, while all four showed marked improvement in the blood and spinal fluid findings.

Cutting and $\mathrm{Mack}^{15}$ report their results in six cases of paresis and one case of cerebral syphilis. The mental condition in all but one showed no improvement. There was no marked change in the neurological findings. The cell counts in the spinal fluids showed a constant and marked reduction, although the Wassermann reaction remained positive and there was no effect on the globulin content.

In eight cases of paresis treated by Myerson ${ }^{16}$ definite changes were seen in the spinal fluid findings after treatment. No real clinical improvement was seen.

Pillsbury ${ }^{17}$ used the intraspinal treatment in eleven cases of advanced paresis. Six of these patients showed improvement either

9. Ravaut, P.: Bull. et mém. Soc. méd. d. hôp. de Paris, 1913, xxxvi, 752.

10. Wile, U. J.: Jour. Am. Med. Assn., 1914, 1xii, 1163; ibid., 1914, 1xiii, 173.

11. Ogilvie, H. S.: Jour. Am. Med. Assn., Nov 28, 1914, 1xiii, 1936.

12. McCaskey, G. W.: Jour. Am. Med. Assn., 1914, 1xii, 187.

13. McCaskey, G. W.: Jour. Am. Med. Assn., 1914, 1xii, 1709.

14. Hough, W. H.: Jour. Am. Med. Assn., 1914, 1xii, 183.

15. Cutting and Mack: Jour. Am. Med. Assn., 1914, 1xii, 903.

16. Myerson: Boston Med. and Surg. Jour., May 7, 1914.

17. Pillsbury, L. B.: Jour. Am. Med. Assn., 1914, 1xiii, 15. 
in the clinical condition or in the laboratory findings. There was only one case which showed decided clinical improvement.

Mapother and Beaton ${ }^{18}$ report their results in four cases of early paresis. They gave five combined intravenous and intraspinous treatments to each patient. There were no appreciable changes noted in the mental condition of the patients. No changes in the blood and spinal fluid Wassermann reactions, which were performed quantitatively, were seen. The pleocytosis and increased globulin content remained unaffected in all cases.

Riggs and Hammes ${ }^{19}$ gave 100 intraspinal treatments to twenty-four patients. In each patient who received over four combined injections the blood Wassermann reaction became negative, except in one case of juvenile paresis. The blood and spinal fluid findings became normal in every way in 75 per cent. of the cases of tabes thus treated. These changes were accompanied by marked clinical improvement. In paresis the results of treatment were less encouraging. The clinical improvement was rarely marked even after a great deal of treatment had been given.

Litterer ${ }^{20}$ reports a series of four cases of paresis and eleven cases of tabes or cerebrospinal syphilis in which the intraspinal injections were used. Ten of the paretics showed improvement. All the cases of cerebrospinal syphilis and of tabes showed marked betterment. Four had had a great deal of salvarsan or neosalvarsan intravenously with no more than temporary improvement of their symptoms.

$\mathrm{McClure}^{21}$ treated four cases of cerebrospinal syphilis, two of tabes dorsalis, one of taboparesis and two of paresis, a total of nine cases. None of his cases were observed for a longer period than five months. All the cases of tabes and cerebrospinal syphilis showed definite improvement, both clinical and in the laboratory findings. One case of paresis showed no improvement, while the other improved greatly.

$\mathrm{Krida}^{22}$ has given seventy-two intraspinal injections in eighteen cases. Out of eight cases of tabes there were four which showed improvement and four which failed to improve. In four cases of paresis there was no improvement in the mental symptoms. One paretic died after an intraspinal injection.

Ayer ${ }^{23}$ has reported his results in sixteen cases. His report is of great value on account of the length of time over which he was able

18. Mapother, E., and Beaton, T.: Lancet, London, 1914, clxxxvi, 1103.

19. Riggs and Hammes: Jour. Am. Med. Assn., 1914, lxiii, 1277.

20. Litterer, W.: Lancet-Clinic, 1915, cxiii, 359.

21. MeClure, C. W.: Boston Med. and Surg. Jour., 1914, clxxi, 520.

22. Krida: Albany Med. Ann., 1914, xxxv, 243.

23. Ayer, James B.: Boston Med. and Surg. Jour., 1914, clxx, 452. 
to observe his patients. The shortest observation is for a period of thirteen months. His most flattering results were in cerebrospinal syphilis, in which condition Ayer believes that persistent treatment in favorable instances, will accomplish a cure. In tabes he believes that an arrest of the process is often to be expected. His results in paresis were far less satisfactory.

Draper, ${ }^{8}$ continuing the observations on Swift and Ellis' original series, reports his results in a series of twenty-five cases. The report is exceptionally careful and detailed. The series includes conditions ranging from tabes associated with painful crises up to brain involvements with marked mental disturbance. There was marked clinical improvement in all classes. The pain and ataxia were usually greatly relieved. Those with bulbar involvement or with mental disturbance showed much improvement, not only in the symptoms, but in the laboratory evidences of the disease. He found that there was apparently no limit to the number of intraspinal injections which might be given when the autosalvarsanized serum was used.

Smith $^{24}$ gave fifty-three injections to twelve patients. In some of his cases, however, he injected undiluted blood serum into the subarachnoid space. In this point only did his technic differ from the original Swift-Ellis method. He used Wile's modification of the Ravaut method fourteen times in twelve additional cases. With this latter method he had unfortunate results, and concludes that it is too dangerous to use. His results with the Swift-Ellis technic were excellent. Clinically, he found marked improvement, and the serological findings in the spinal fluid either diminished or returned to normal. The pleocytosis in the spinal fluid was affected first, next the Wassermann reaction was diminished, but the increased globulin content was the slowest of the three tests to disappear.

The general conclusion which can be drawn from the above reports indicates that by this method some changes may occur in paresis, but that much permanent improvement is scarcely to be expected. On the other hand, the effect of the treatment in cerebrospinal syphilis and tabes dorsalis seems to be extremely beneficial. The symptomatic improvement is often marked and a diminution or a complete disappearance of the serological findings in both the blood and the spinal fluid may be expected in most instances.

The method has been criticized on the ground that it is dangerous. A careful search of the literature shows the following fatalities:

Loren $\mathrm{z}^{25}$ treated five patients with paresis. Two died. He then gave up this particular technic, stating that it "has in our hands been

24. Smith, L. D.: Jour. Am. Med. Assn., 1915, 1xiv, 1563.

25. Lorenz: Wisconsin Med. Jour., 1913, xii, 171. 
very irritating and caused alarming symptoms." Pillsbury ${ }^{17}$ reports the death of a paretic shortly after an intradural treatment. Krida ${ }^{22}$ also reported the death of a paretic. Neither Swift and Ellis,, 3 Ayer, ${ }^{23}$ Draper, ${ }^{8}$ nor Smith $^{24}$ have had a fatality in their extensive series. It is noteworthy that the reported deaths have been among paretics, and that no fatalities have occurred after the treatment of tabetics. The number of fatalities in the total number of treatments is not alarming, considering the desperate outlook in this condition. No account is taken of fatalities occurring after any kind of intradural treatment except that of Swift and Ellis.

We wish to report our results with the intraspinal injection of autosalvarsanized serum in syphilitic affections of the central nervous system. The number of our cases is limited but the value of our report may be increased by the length of time that some of them have been under observation. Our first patient came under treatment in January, 1913, and the second one a short time later (March, 1913). These two patients were under our care so short a time that they are scarcely worthy of consideration.

In addition to these two preliminary cases we have observed one case of extremely acute cerebrospinal syphilis, eight cases of definite tabes or cerebrospinal syphilis and one case of paresis.

We have followed rigidly the Swift-Ellis technic. From one-half hour to one hour after an intravenous injection of salvarsan or neosalvarsan from 40 to 50 c.c. of blood are withdrawn with aseptic precautions from the patient by venipuncture, using a McRae needle fitted to a 50 c.c. centrifuge tube. The tube is then corked with a sterile cork; and after the blood has clotted, the clot is separated from the sides of the tube with a sterile platinum wire. The serum is then separated in a rapid centrifuge, then withdrawn with a sterile capillary pipet and ejected into a sterile, graduated, glass-stoppered rnixing cylinder. Especial care must be taken to have the serum absolutely free from red blood cells and fibrin. Sufficient sterile normal sodium chlorid solution is added to make the desired dilution, the cylinder is stoppered and is placed in a water bath at $56 \mathrm{C}$. for one-half hour. On the following day lumbar puncture is performed. Fifteen c.c. of spinal fluid are allowed to run out into a graduated test tube, when the barrel of a 25 c.c. Luer syringe is attached to the free end of the lumbar puncture needle by the intervention of a section of rubber tubing 12 inches long, fitted with slip-joint connections. When the spinal fluid appears in the syringe (which is held upright so that it may be used as a graduated funnel) the serum mixture is poured in it. This is allowed to flow by gravity. 


\section{ABSTRACT OF CASE HISTORIES}

An abstract of the histories of these cases follows:

CASE 1.-(Table 1.) W. I. S. Cerebrospinal syphilis. Male, 29 years old. Married. The intraspinous treatment was begun March 13,1913. The year before the patient consulted us he had been temporarily unable to void urine and had had to be catheterized. Five months later he began to have shooting pains in the legs which were thought to be sciatica. Attacks of pain in the

TABle 1.-(Case 1.) Cerebrospinal Syphilis

W. I. S., aged 29. Cerebrospinal syphilis. Duration: one year. Syphilis admitted. Result: marked improvement.

\begin{tabular}{|c|c|c|c|c|c|c|}
\hline \multirow[b]{2}{*}{ Date } & \multirow[b]{2}{*}{$\begin{array}{c}\text { Blood } \\
\text { Wasser- } \\
\text { mann } \\
\text { Reaction }\end{array}$} & \multicolumn{3}{|c|}{ Cerebrospinal Fluid } & \multirow[b]{2}{*}{$\begin{array}{l}\text { Intra- } \\
\text { venous } \\
\text { Salvarsan } \\
\text { gm. }\end{array}$} & \multirow[b]{2}{*}{$\begin{array}{l}\text { Serum } \\
\text { Intra- } \\
\text { spinously } \\
\text { c.c. pct. }\end{array}$} \\
\hline & & $\begin{array}{c}\text { Cells } \\
\text { per c.mm. }\end{array}$ & $\begin{array}{c}\text { Noguchi } \\
\text { Globulin } \\
\text { Test }\end{array}$ & $\begin{array}{l}\text { Wasser- } \\
\text { mann } \\
\text { Reaction } \\
\text { No. c.c. }\end{array}$ & & \\
\hline $2 / 7 / 13$ & ++ & 153 & ++ & $0.1,++$ & $\ldots \ldots \ldots$ & $\ldots$. \\
\hline $\begin{array}{l}2 / 13 / 13 \\
2 / 26 / 13\end{array}$ & & & & $\begin{array}{c}0,2,1+ \\
\ldots \ldots \ldots \ldots \\
\ldots \ldots \ldots\end{array}$ & $\begin{array}{ll}914, & 0.3 \\
914, & 0.5\end{array}$ & $\begin{array}{l}\ldots \ldots \ldots \\
\ldots \ldots \ldots\end{array}$ \\
\hline $\begin{array}{l}3 / 13 / 13 \\
3 / 14 / 13\end{array}$ & $\cdots$ & ${ }^{\prime}{ }_{16} \cdots$ & $\cdots+\cdots$ & $0.3,+7+$ & $914,0.6$ & $20 \cdots \cdots$ \\
\hline $\begin{array}{l}5 / 14 / 13 \\
5 / 15 / 13\end{array}$ & …...... & & 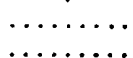 & $0.3 . \cdots+$ & $914,0.6$ & $25 \cdots \cdots$ \\
\hline $6 / 22 / 13 \dagger$ & $\cdots \cdots \cdots$ & - & …......... & …....... & $\dddot{9 i 4}, 0.6$ & …....... \\
\hline $7 / 10 / 13$ & …...... & $\dddot{0}$ & - & $0.3,+\ddot{+}+$ & $\begin{array}{l}0,0,0.0 \\
\cdots \ldots . . .\end{array}$ & $25 \quad 40$ \\
\hline $\begin{array}{l}8 / 21 / 13 \\
8 / 22 / 13\end{array}$ & $\ldots \ldots \ldots \ldots$ & $\begin{array}{l}\ldots \ldots \ldots \\
\ldots \ldots \ldots \ldots \\
\ldots\end{array}$ & $\ldots \ldots \ldots$ & $0.2,+$ & $\begin{array}{c}606,0.5 \\
\ldots \ldots \ldots\end{array}$ & $25{ }^{30}$ \\
\hline $\begin{array}{l}10 / 3 / 13 \\
10 / 16 / 13 \\
12 / 1 / 13 \\
12 / 3 / 13\end{array}$ & $\begin{array}{c}\ldots \ldots \ldots \\
\cdots \ldots \ldots \\
\ldots \ldots\end{array}$ & ${ }_{3.3}$ & $\begin{array}{c}\cdots \cdots \cdots \\
\cdots \ldots \ldots \\
\cdots\end{array}$ & o.5, & $\begin{array}{l}606,0.55 \\
606,0.55 \\
606,0.5 \\
\ldots \ldots \ldots \ldots\end{array}$ & 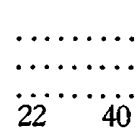 \\
\hline $\begin{array}{l}1 / 26 / 14 \\
1 / 27 / 14\end{array}$ & $\begin{array}{l}\ldots \ldots \ldots \ldots \\
\cdots \ldots \ldots \ldots\end{array}$ & 13 & $\cdots$ & $\begin{array}{l}1.0, \ldots++ \\
0.5, \cdots \cdots\end{array}$ & $\begin{array}{c}606,0.5 \\
\ldots \ldots \ldots .\end{array}$ & $25{ }^{\prime}{ }_{40}$ \\
\hline $2 / 8 / 14$ & $+t+$ & & & …....... & 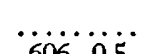 & $\ldots$. \\
\hline $3 / 27 / 14$ & $\cdots \cdots \cdots$ & $\ddot{3}$ & \pm & $0.8+++$ & $\ldots \ldots \ldots$ & $\ddot{25}$ \\
\hline
\end{tabular}

*Patient has been having $\mathrm{HgCl}_{2}$ injections.

$\uparrow$ General condition poor. Luetic orchitis.

$¥$ General condition much improved.

legs and abdomen were a frequent occurrence. Diplopia and ptosis of the left eyelid appeared three weeks before he was seen by us. At examination the pupils reacted sluggishly to both light and accommodation and were unequal in outline. The knee and ankle jerks were absent. The sensations of touch, pain, heat and cold were diminished all over the body except on the face and neck. The blood showed a very strongly positive Wassermann reaction. The spinal 
fluid showed a great globulin increase, 153 cells to the c.mm., and a Wassermann reaction strongly positive with 0.2 c.c. of the fluid. The process was advancing rapidly, for between the time of the first examination and the first treatment, a period of nineteen days, he grew rapidly worse. It was almost impossible for him to get about on account of an ever increasing paresis of the right leg.

The improvement was very slow in this case. His general condition was poor and he had a complicating luetic orchitis. It was not until he had received eight intravenous injections and four intraspinous injections, stretching over eight months, that he reported himself as being free from pain in the legs, and suffered only an occasional twinge in the chest. His improvement has been steady since that time. His last treatment was in March, 1914.

Summary of Treatment.-This patient has been under observation over two years. In that time he has received twelve intravenous injections of salvarsan (a total of $5.4 \mathrm{gm}$.) and seven intraspinal injections. Further, he has received much mercury, both by injection and by inunction.

Results and Present Condition.-In May, 1915, the patient reported that he had had only one attack of pain in the last year. He has returned to his business, which he is pursuing as usual. He has regained the power in his right leg and he walks perfectly well. The physical findings are much the same as when he was first observed, except that the sensations have returned to a marked degree. There has been marked improvment in the laboratory findings in both the blood and spinal fluid.

CASE 2.-(Table 2.) W. M. B. Moderately advance tabes. Male, 45 years old. Single. The intraspinous treatment was begun May 8, 1913. The patient was infected with syphilis at the age of 25 . He walked unsteadily and had attacks of lancinating pains in the legs for two years previous to the time at which he was first seen by us. He had had three intravenous injections of salvarsan $(0.6 \mathrm{gm}$. each) before consulting us. At examination, the pupils were unequal but reacted to light and accommodation. The knee and ankle jerks were absent. There was a large area of hypalgesia over the outside of the left thigh. Romberg's sign was present. The Wassermann reaction in the blood was strongly positive. The spinal fluid showed a moderately increased globulin content, 75 cells per c.mm., and a Wassermann positive in 0.1 c.c. of spinal fluid.

After seven injections of neosalvarsan and five intraspinal injections the laboratory findings showed decided improvement. The globulin disappeared and the cell count was reduced from 75 to 5 per c.mm. Sensory changes were less marked and the patient walked better. It is interesting to note that the lancinating pains in this case disappeared after the first intraspinal treatment and have never returned. The patient was then put on mercurial inunctions, and after a short time he became very uncertain on his feet and had much increased numbness and tingling, so much so that he could not walk without assistance. The mercury was discontinued and he received four intravenous injections of salvarsan and one intraspinal injection with a very marked improvement in his ability to walk.

After receiving eighteen intravenous injections and fourteen intraspinal injections, the patient was so much improved that he went west and took up his duties as a ranch owner, performing all the duties of ranch life, walking, driving, riding, plowing and so forth, without difficulty.

He returned, after an absence of ten months, when we found his blood Wassermann reaction negative. The globulin content of the spinal fluid was not increased. The cells were within normal limits and the Wassermann reaction was strongly positive only when 0.5 c.c. of fluid was used.

Summary of Treatment.--This patient was under observation over two years. He has received in all twenty intravenous injections of salvarsan or neosalvarsan (the equivalent of $10.7 \mathrm{gm}$. salvarsan) and fifteen intraspinal injections. He had practically no reaction after either form of treatment. 


\section{TABLE 2.-(CASE 2.) TABes Dorsalis}

W. M. B., aged 45. Moderately advanced tabes dorsalis. Duration: two years. Syphilis admitted. Result : marked improvement.

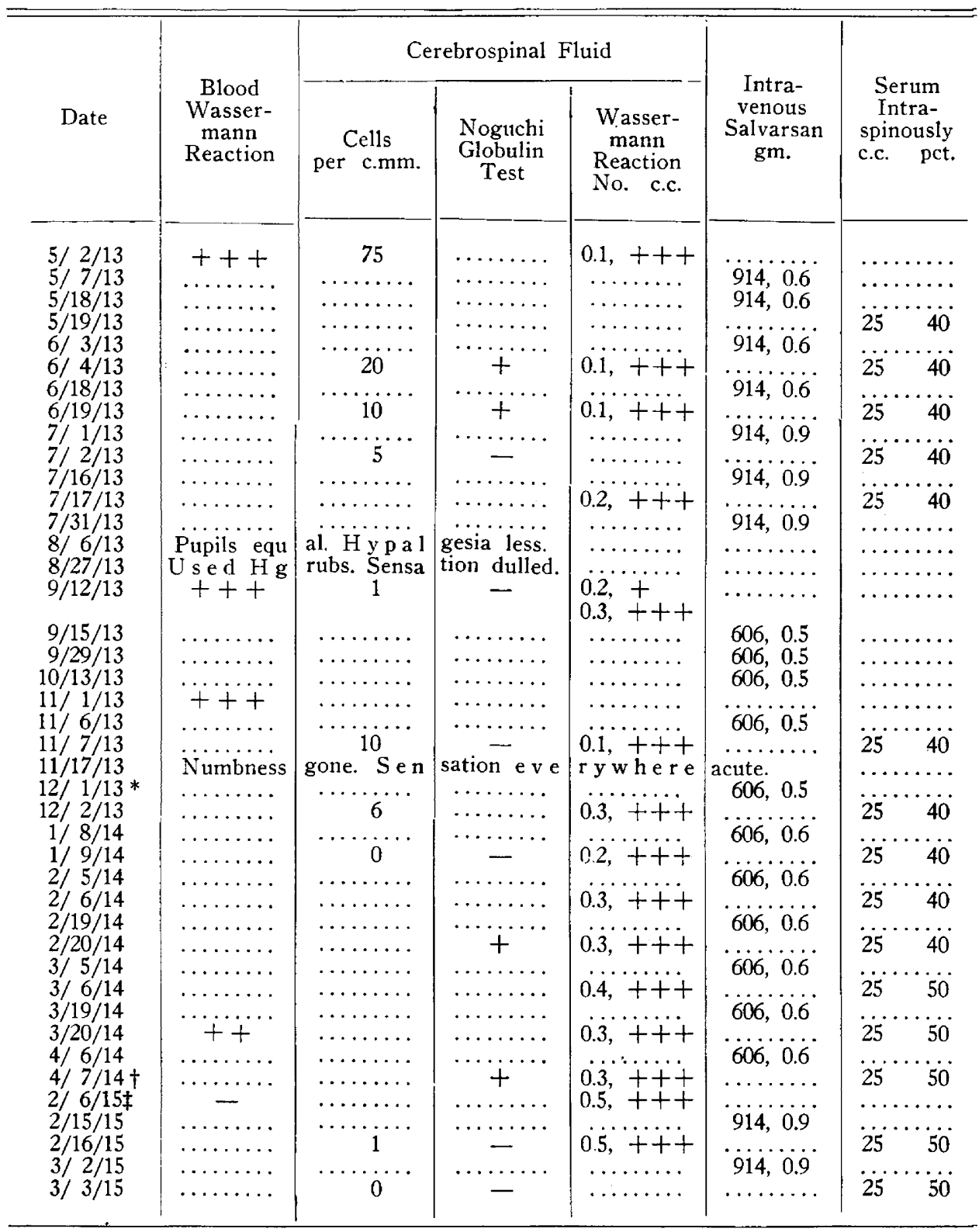

* Surer on feet. Walks better.

$\dagger$ No sensory disturbance subjective or objective. Can walk and run.

$\$$ Also negative when done with two and three times the usual amount of patient's serum. 
Results and Present Condition.-The patient is now able to follow his usual occupation without difficulty. April 30,1915 , he wrote that he walked normally, though he felt a little stiffness from his knees down and that he could cover three or four miles a day without difficulty. There has been no change in the physical findings except that practically no sensory disturbances exist. There has been a marked improvement in the serological findings. From a functional and symptomatic point of view this patient is vastly improved.

CASE 3.-(Table 3.) H. O. B. Male, aged 34. Single. Cerebrospinal syphilis with very acute onset of symptoms. Had been drinking heavily and was brought to the Cleveland City Hospital for what was presumed to be

table 3.-(Case 3.) Cerebrospinal Syphilis

H. O. B., aged 34 . Acute cerebrospinal syphilis. Result: marked improvement, Cleveland City Hospital.

\begin{tabular}{|c|c|c|c|c|c|c|}
\hline \multirow[b]{2}{*}{ Date } & \multirow{2}{*}{$\begin{array}{c}\text { Blood } \\
\text { Wasser- } \\
\text { mann } \\
\text { Reaction }\end{array}$} & \multicolumn{3}{|c|}{ Cerebrospinal Fluid } & \multirow{2}{*}{$\begin{array}{c}\text { Intra- } \\
\text { venous } \\
\text { Salvarsan } \\
\text { gm. }\end{array}$} & \multirow{2}{*}{$\begin{array}{l}\text { Serum } \\
\text { Intra- } \\
\text { spinously } \\
\text { c.c. pet }\end{array}$} \\
\hline & & $\begin{array}{c}\text { Cells } \\
\text { per c.mm. }\end{array}$ & $\begin{array}{l}\text { Noguchi } \\
\text { Globulin } \\
\text { Test }\end{array}$ & $\begin{array}{l}\text { Wasser- } \\
\text { mann } \\
\text { Reaction } \\
\text { No. c.c. }\end{array}$ & & \\
\hline $\begin{array}{l}3 / 21 / 14 * \\
4 / 13 / 14 \dagger \\
4 / 27 / 14 \\
4 / 28 / 14 \\
5 / 2 / 14 \\
5 / 12 / 14 \\
5 / 19 / 14 \\
5 / 20 / 14 \\
6 / 2 / 14 \\
6 / 3 / 14 \\
6 / 5 / 14 \\
6 / 18 / 14 \\
6 / 19 / 14 \\
7 / 8 / 14 \\
7 / 9 / 14 \\
7 / 27 / 14 \\
7 / 28 / 14 \ddagger \\
8 / 9 / 14 \S \\
5 / 31 / 15 \pi\end{array}$ & 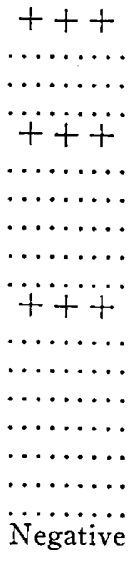 & 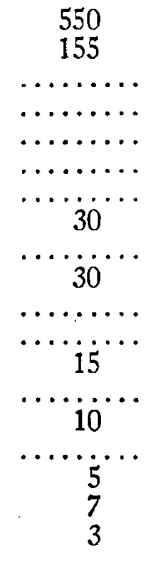 & 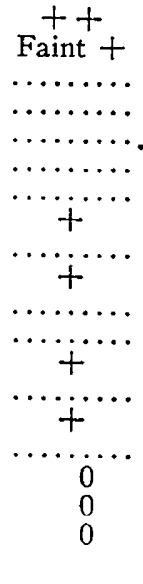 & 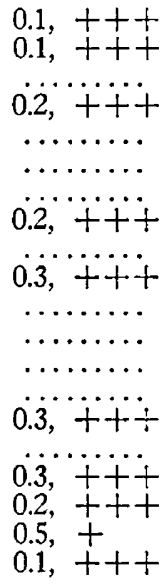 & 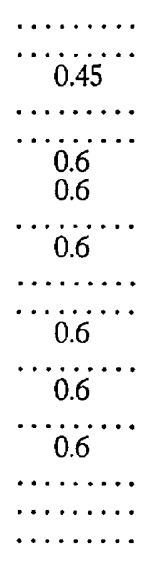 & 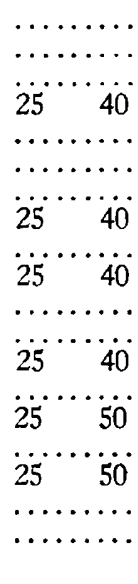 \\
\hline
\end{tabular}

* Wild delirium followed by unconsciousness with fever and signs of acute meningeal involvement. Double papillitis.

$\div$ Mercury biniodid, $1 / 2$ gr. intramuscularly, eighteen doses.

\$ Serum followed by very severe reaction. Heavy trace of albumin in urine.

$\S$ Discharged from the hospital with slight facial paresis and paresis of left arm. Much improved.

T Only slight slurring of speech and paresis of left arm. No treatment from 8/9/14 to $5 / 21 / 15$.

delirium tremens. Two weeks after admission the patient developed a paresis of the left arm and of the left side of the face associated with a marked rigidity of the neck and double Kernig's sign and a double Babinski reflex. The pupils reacted to light. The right was larger than the left. The temperature rose to 103.6 and the pulse to 108 . He had incontinence of both urine 
and feces. The spinal fluid was turbid, showed 550 cells per c.mm., a heavy Noguchi globulin reaction and a positive Wassermann reaction in 0.1 c.c. of the spinal fluid. Under intramuscular injections of mercury biniodid, gr. $1 / 2$, of which he received eighteen, together with large doses of potassium iodid, the acute symptoms cleared up, but the patient was very weak. His mentality was slow and his speech halting. His first intraspinal injection was given April 28, 1914. During three months following the patient received seven intravenous injections of salvarsan, a total of $4.05 \mathrm{gm}$., and four intraspinous injections of 25 c.c. of 40 per cent. serum and two intraspinous injections of 25 c.c. of 50 per

\section{TABLE 4.-(CAse 4.) Tabes Dorsalis}

C. H. Z., aged 44. Tabes dorsalis several years' duration. Syphilis denied. Result: marked improvement.

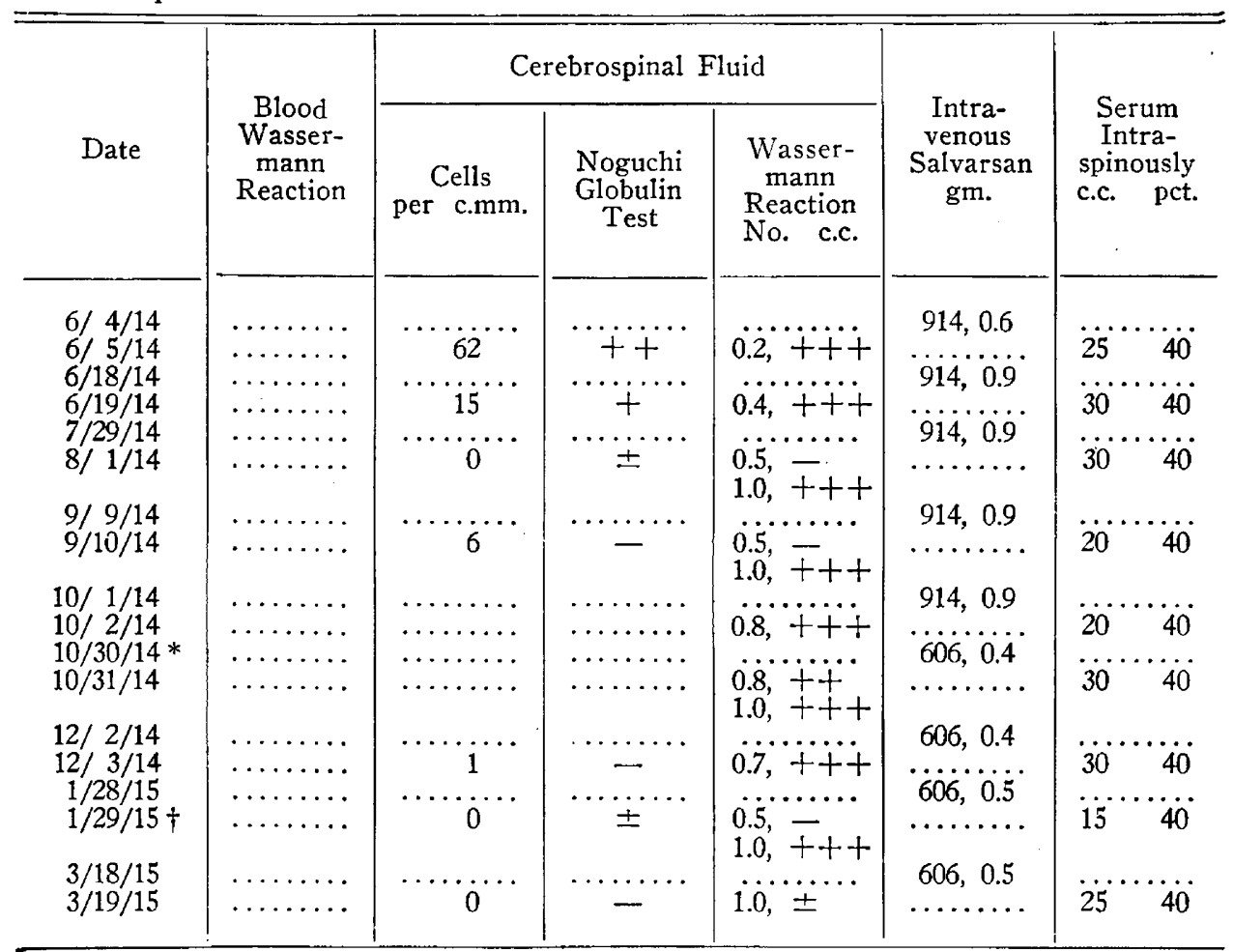

* Gained in weight. No crises since $10 / 2$.

$\dagger$ No crises. Occasional twinge in leg.

cent. serum. After the last injection the patient had a severe reaction, characterized by pains in the head and abdomen and by albuminuria. While under intraspinal treatment the patient gained 20 pounds in weight. His mentality improved greatly and his general strength increased. He left the hospital and returned to his work as a manager of a shoe store, which he carried out to the satisfaction of his employers. He was seen again nine months after his discharge from the hospital. The patient was well nourished. His speech was slightly halting, but questions were answered intelligently. He showed $\mathfrak{n}$; tendency to the speech defects typical of paresis. The pupils reacted a little sluggishly to light. The paresis of the left arm was still present but no other abnormalities were made out on physical examination. The blood Wassermann 
reaction was negative. The spinal fluid showed three cells per cubic millimeter, a negative Noguchi globulin reaction and the Wassermann reaction gave a strongly positive reaction with 0.7 c.c. of the fluid.

In this case the acuteness of the symptoms at onset is very striking. Under treatment the symptomatic improvement was very marked, while the serological findings in biood and spinal fuid remained almost the same, except for the diminution in cells and globulin content in the spinal fluid.

Results and Present Condition.-Observation after nine months without treatment showed that the patient had returned to economic efficiency and it is interesting to note that during this time his serological improvement had become very marked. His process has not only been arrested but has receded to an apparently harmless degree of latency. He should, of course, receive treatment until all the serological signs of the disease have disappeared.

Summary of Treatment.-This patient received seven intravenous injections (a total of $4.05 \mathrm{gm}$. salvarsan) and six intraspinal injections preceded by $9 \mathrm{gr}$. of mercury biniodid intramuscularly, during a period of a little less than five months.

CASE 4.-(Table 4.) C. H. Z. Tabes dorsalis (moderately advanced). Man, 44 years old. Had been troubled for some years with gastric crises and with incontinence of urine. No history of a luetic infection could be obtained. The pupils were pin point and did not react to light. Knee and ankle jerks were lacking, muscle sense was impaired and Romberg's sign was present. Received first intraspinous treatment June 5, 1914. After the first combined treatment there was a marked subsidence of pain, and after the third treatment he began to show decided improvement in general condition. The spinal fluid taken after two combined treatments showed a disappearance of the lymphocytosis and with 0.5 c.c. the Wassermann reaction was negative.

Summary of Treatment.-He has received neosalvarsan or salvarsan intravenously nine times (the total being equivalent to $4.6 \mathrm{gm}$. of salvarsan) and nine serum injections. The reaction to the intraspinous treatments were at first severe but latterly they have been less marked.

Present Condition.-Clinically his present condition is greatly improved. The pains have disappeared, except for recrudescences in mild form when he is fatigued. His weight has increased, he feels well and his economic efficiency has been restored. Physical examination shows no change in pupils or reflexes but the Romberg sign is less marked and the muscle sense is improved. The laboratory findings are very gratifying. The cell count is normal, globulin is absent, and even when 1.0 c.c. of spinal fluid was employed the result of the Wassermann reaction was negative $( \pm)$.

Case 5.-(Table 6.) Mrs. W. A. D. Early tabes. Female, 34 years of age. Married. Complained of occasional incontinence of urine and stumbling. The symptoms had been in evidence for one and one-half years. Infection had taken place twelve or thirteen years previously. At that time she had received "pills" for a year only. Examination showed inequality of pupils with failure to react to light, absence of knee and ankle jerks and Romberg's sign. For a year before consulting us some soluble mercurial preparation had been administered intensively. Under this therapy she made some improvement, but it was slight and very slow. The Wassermann reaction, using blood serum, was strongly positive and the spinal fluid showed 95 cells per c.mm. a positive globulin test, a Wassermann reaction when only 0.1 c.c. was employed.

The improvement in this case after the institution of intravenous and intraspinous treatment was rapid and striking. After the first two treatments she reported that she was able to run up stairs from the basement to the second story, while previously in ascending stairs she had to stop after climbing 
up a few steps "to take the twist out of her legs." The subarachnoid fluid showed the Wassermann reaction to be less than one-fifth as strong as it had been. Altogether this patient has been under observation six months.

Summary of Treatment.-The patient has taken six injections of neosalvarsan or salvarsan (the total being equivalent to $3.0 \mathrm{gm}$. of salvarsan) and has been given two intraspinous injections.

Present Condition.-When the spinal fluid was examined last the lymphocytosis and the trace of globulin had disappeared, and the Wassermann reaction was negative with 0.5 c.c., though positive with 1.0 c.c. In addition, the clinical result in this case has been very striking. The incontinence has cleared up, the gait has improved. She is much stronger and can accomplish more. The pupillary reaction and the ankle and knee jerks are unchanged.

TABLE 5.-(CASE 5.) Tabes Dorsalis

Mrs. W. A. D., aged 34. Early tabes dorsalis. Syphilis admitted. Result: marked improvement.

\begin{tabular}{|c|c|c|c|c|c|c|}
\hline \multirow[b]{2}{*}{ Date } & \multirow{2}{*}{$\begin{array}{c}\text { Blood } \\
\text { Wasser- } \\
\text { mann } \\
\text { Reaction }\end{array}$} & \multicolumn{3}{|c|}{ Cerebrospinal Fluid } & \multirow{2}{*}{$\begin{array}{l}\text { Intra- } \\
\text { venous } \\
\text { Salvarsan } \\
\text { gm. }\end{array}$} & \multirow{2}{*}{$\begin{array}{l}\text { Serum } \\
\text { Intra- } \\
\text { spinously } \\
\text { c.c. pct. }\end{array}$} \\
\hline & & $\begin{array}{l}\text { Cells } \\
\text { per c.mm. }\end{array}$ & $\begin{array}{c}\text { Noguchi } \\
\text { Globulin } \\
\text { Test }\end{array}$ & $\begin{array}{l}\text { Wasser- } \\
\text { mann } \\
\text { Reaction } \\
\text { No. c.c. }\end{array}$ & & \\
\hline $\begin{array}{l}10 / 14 / 14 \\
10 / 19 / 14 \\
10 / 20 / 14 \\
11 / 13 / 14 * \\
12 / 30 / 14 \\
12 / 31 / 14 \dagger \\
\\
1 / 22 / 15 \\
2 / 5 / 15 \\
3 / 5 / 15 \\
4 / 8 / 15\end{array}$ & 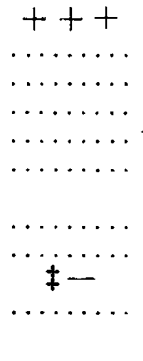 & $\begin{array}{l}\cdots \ldots \\
{ }_{95} \\
\cdots \cdots \cdots \\
\cdots \cdots \cdots \\
\cdots \cdots\end{array}$ & $\begin{array}{l}\cdots \cdots \\
\cdots \\
\cdots \cdots \\
\cdots \cdots \\
\cdots \cdots \\
\cdots \cdots \\
\cdots \cdots \\
\cdots \cdots \\
\cdots \cdots \\
-\end{array}$ & $\begin{array}{c}\ldots \cdots \\
0.1,++++ \\
\ldots \ldots \\
0.5,+ \\
0.1,+++ \\
\ldots \cdots \\
\cdots \cdots \\
0.5, \bar{\cdots} \\
1.0,+++\end{array}$ & $\begin{array}{c}914,0.6 \\
\ldots \ldots \ldots \\
914,0.9 \\
914,0.9 \\
\ldots 13 \ldots .9 \\
914,0.9 \\
606,0.4 \\
606,0.4 \\
\ldots \ldots \ldots\end{array}$ & $\begin{array}{l}\cdots \ldots \\
25 \\
\cdots \cdots \\
21 \\
\ldots \ldots\end{array}$ \\
\hline
\end{tabular}

* Already feels much better.

$\dagger$ Coordination much improved.

$\$$ Also negative when reaction was performed using two and three times usual amount of patient's serum.

CASE, 6.-(Table 6.) D. W. H. Moderately advanced tabes. Man, aged 39. He acquired syphilis in 1901. His treatment was interrupted after six months on account of very severe typhoid fever which intervened. Following convalescence from typhoid, iodid and mercury were taken by mouth periodically, and since then he has had broken courses of mercury. The first symptoms of nervous disturbance came in March, 1913. After this he had a nervous break down associated with dyspepsia. In October, 1914, he noted stiffness and numbness in the extremities. Soon after he had severe pain in the back and had much difficulty with locomotion on account of "stiffness in his legs."

The patient has received a portion of his treatment from Dr. H. M. Brundage of Columbus, who has very courteously furnished us with a synopsis of his findings. When the patient was first seen by him Dec. 28, 1914, the blood serum Wassermann reaction was negative and the spinal fluid showed 150 cells 
per cubic millimeter, a decided trace of globulin and a strongly positive Wassermann reaction, the quantities varying from 0.1 to 0.5 c.c. (expressed in terms of modified technic). Dr. Brundage administered a total of three intravenous and three intraspinous injections. The patient noted decided improvement three days after his first treatment.

When we saw the patient the pupils showed inequality but reacted promptly to light and accommodation. The knee jerks and ankle jerks were absent. Muscle sense was impaired. There were marked sensory changes. A slight Romberg sign was present and the patient had a typical tabetic gait. The spinal fluid showed that the cell count had diminished to 2 per cubic centimeter, the butyric acid reaction was only faintly positive and the Wassermann reaction was negative with 0.5 c.c., but strongly positive with 1.0 c.c.

Table 6.-(Case 6.) Moderately Advanced Tabes

D. W. H., aged 39. Moderately advanced tabes. Result: marked improvement.

\begin{tabular}{|c|c|c|c|c|c|c|}
\hline \multirow[b]{2}{*}{ Date } & \multirow{2}{*}{$\begin{array}{c}\text { Blood } \\
\text { Wasser- } \\
\text { mann } \\
\text { Reaction }\end{array}$} & \multicolumn{3}{|c|}{ Cerebrospinal Fluid } & \multirow{2}{*}{$\begin{array}{c}\text { Intra- } \\
\text { venous } \\
\text { Salvarsan } \\
\text { gm. }\end{array}$} & \multirow{2}{*}{$\begin{array}{l}\text { Serum } \\
\text { Intra- } \\
\text { spinously } \\
\text { c.c. pet. }\end{array}$} \\
\hline & & $\begin{array}{c}\text { Cells } \\
\text { per c.mm. }\end{array}$ & $\begin{array}{l}\text { Noguchi } \\
\text { Globulin } \\
\text { Test }\end{array}$ & $\begin{array}{l}\text { Wasser- } \\
\text { mann } \\
\text { Reaction } \\
\text { No. c.c. }\end{array}$ & & \\
\hline $\begin{array}{c}\text { Previous to } \\
\text { M a rch, } \\
1915 * \text { * } \\
3 / 13 / 15 \\
4 / 9 / 15 \\
4 / 10 / 15\end{array}$ & $\begin{array}{c}- \\
\ldots \ldots \\
\ldots \ldots\end{array}$ & $\cdots \cdots \cdots$ & $\ldots \ldots \ldots$ & $\begin{array}{l}0.2,+++ \\
\ldots \ldots \ldots \\
0.5, \ldots \cdots\end{array}$ & $\begin{array}{c}\cdots \ldots \cdots \\
0.4 \\
\cdots \cdots\end{array}$ & ${ }_{30} \cdots \cdots$ \\
\hline $\begin{array}{l}5 / 7 / 15 \\
5 / 8 / 15\end{array}$ & $\begin{array}{l}\ldots \ldots \ldots \ldots \\
\cdots \ldots+\cdots\end{array}$ & $\ldots$ & $\cdots \ldots$ & $\begin{array}{l}1.0,++++ \\
0.5, \cdots \cdots\end{array}$ & $\begin{array}{c}0.4 \\
\ldots \ldots \ldots\end{array}$ & $30 \cdots 5$ \\
\hline $\begin{array}{l}6 / 11 / 15 \\
6 / 12 / 15\end{array}$ & $\begin{array}{l}\ldots \ldots \ldots \\
\cdots \cdots \cdots\end{array}$ & $\ldots \ldots \ldots$ & 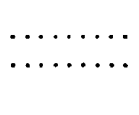 & $0.7, \overline{+}$ & $\begin{array}{c}0.4 \\
\ldots \ldots \ldots\end{array}$ & $28 \cdots$ \\
\hline $\begin{array}{l}7 / 30 / 15 \\
7 / 31 / 15\end{array}$ & $\cdots+\cdots$ & $\cdots \cdots_{i} \cdot$ & Faint + & $\begin{array}{l}0.5, \pm \\
1.0, \pm\end{array}$ & $\begin{array}{c}0.5 \\
\ldots \ldots \ldots\end{array}$ & $32 \quad 50$ \\
\hline
\end{tabular}

* While he was under the care of Dr. W. H. Brundage of Columbus, Ohio, to whom we are indebted for the above data.

$\dagger$ Three injections of $0.6 \mathrm{gm}$. followed by three intraspinal treatments of 20 c.c. of

50 per cent. serum- $\mathrm{NaCl}$ mixture.

Marked clinical improvement.

Summary of Treatment.- - He has received in all seven intravenous injections of salvarsan, a total of $3.5 \mathrm{gm}$., and seven intraspinal injections of salvarsanized serum.

Present Condition.-At present the appreciation of pain has returned in both legs, muscle sense is accurate and the vibratory sense has returned over the greater part of both legs. The patient has no pains and no stiffness, he takes exercise and goes about his business with zest and is living a normally efficient existence. The Wassermann reaction is negative in the blood. The globulin content of the spinal fluid is not increased. There is one cell to the cubic millimeter and the Wassermann reaction on the spinal fluid is but a plus-minus reaction when 1.0 c.c. of the spinal fluid is used. This case can fairly be considered at present a clinical and serological cure. 
CASE 7.-('Table 7.) H. R. Moderately advanced tabes. Male, aged 32. Married. First intraspinal treatment given April 23, 1914. Patient was infected eleven years ago. There were no noticeable secondary manifestations so that no treatment was taken until two years after the infection, when sores appeared in the mouth and throat. For five years the patient had suffered excruciating, lancinating pains in the legs. The crises of pain sometimes lasted for thirty-six hours. There was occasionally involuntary micturition. The patient was a well developed young man. The pupils were widely dilated and reacted to light. The knee and ankle jerks were absent. There was a slight Romberg's

Table 7.-(Case 7.) Moderately Advanced Tabes

H. R., aged 32. Moderately advanced tabes. Duration: five years. Syphilis admitted. Result : improvement.

\begin{tabular}{|c|c|c|c|c|c|c|}
\hline \multirow[b]{2}{*}{ Date } & \multirow{2}{*}{$\begin{array}{c}\text { Blood } \\
\text { Wasser- } \\
\text { mann } \\
\text { Reaction }\end{array}$} & \multicolumn{3}{|c|}{ Cerebrospinal Fluid } & \multirow{2}{*}{$\begin{array}{l}\text { Intra- } \\
\text { venous } \\
\text { Salvarsan } \\
\text { gm. }\end{array}$} & \multirow{2}{*}{$\begin{array}{l}\text { Serum } \\
\text { Intra- } \\
\text { spinously } \\
\text { c.c. pct. }\end{array}$} \\
\hline & & $\begin{array}{c}\text { Cells } \\
\text { per c.mm. }\end{array}$ & $\begin{array}{l}\text { Noguchi } \\
\text { Globulin } \\
\text { Test }\end{array}$ & $\begin{array}{l}\text { Wasser- } \\
\text { mann } \\
\text { Reaction } \\
\text { No. c.c. }\end{array}$ & & \\
\hline $\begin{array}{l}3 / 28 / 14 \\
4 / 22 / 14 \\
4 / 23 / 14\end{array}$ & $\begin{array}{l}+++* \\
\ldots \ldots \ldots \\
\ldots \ldots \ldots\end{array}$ & $\cdots \cdots \cdots$ & $\begin{array}{c}\cdots \cdots \cdots \\
\cdots+\cdots \\
\dddot{+}\end{array}$ & $0.4 \cdots$ & $\begin{array}{c}\ddot{9} \ddot{14}, \ddot{0} \ddot{9} \\
\ldots \ldots \ldots\end{array}$ & $\ddot{2}{ }^{\cdots} \cdots \ddot{40}_{\dagger}^{+}$ \\
\hline $\begin{array}{l}5 / 27 / 14 \\
5 / 28 / 14\end{array}$ & $\ldots \ldots \ldots$ & $\cdots m_{0} \cdot$ & $\cdots \cdots \cdots$ & $0.5, \ldots \cdots$ & $\begin{array}{l}606,0.4 \ddagger \\
\ldots \ldots \cdots\end{array}$ & $\ddot{25}{ }^{\prime}{ }_{40}$ \\
\hline $\begin{array}{l}6 / 17 / 14 \\
6 / 18 / 14\end{array}$ & $\ldots \ldots \ldots$ & $\cdots \ddot{3}^{\prime} \cdot$ & $\cdots{ }^{\prime} \cdots$ & $\begin{array}{l}0.5, \div \\
1.0,+1+1\end{array}$ & $\begin{array}{c}606,0.4 \\
\cdots \cdots \cdots\end{array}$ & $\ddot{2} 5$ \\
\hline $\begin{array}{l}7 / 22 / 14 \\
7 / 23 / 14\end{array}$ & $\ldots \ldots \ldots$ & $\cdots \cdots \cdots$ & $\cdots \cdots \cdots$ & $\begin{array}{l}0.5,- \\
1.0,+++\end{array}$ & $\begin{array}{c}606,0.45 \S \\
\ldots \ldots \ldots\end{array}$ & $\ddot{20} \ddot{40}^{\prime}$ \\
\hline $\begin{array}{l}9 / 3 / 14 \\
9 / 5 / 14\end{array}$ & $\ddot{+} \ddot{+} \ddot{+}$ & $\cdots \cdots_{0}^{\cdots}$ & ${ }^{\cdots}+\cdots$ & $0.5, \bar{\cdots}$ & $\begin{array}{l}606,0.4 \\
\ldots \ldots \ldots\end{array}$ & $20 \cdots \cdots$ \\
\hline $\begin{array}{l}1 / 6 / 15 \\
1 / 7 / 15\end{array}$ & $\ldots \ldots \ldots$ & $\cdots \ldots \ldots$ & $\cdots \cdots \cdots$ & $\ddot{1.0}-\cdots$ & $\begin{array}{c}914,0.6 \\
\ldots \ldots \ldots \ldots\end{array}$ & $\ddot{25}{ }^{40}$ \\
\hline
\end{tabular}

*This reaction was so strong that it was given with one-eighth the usual amount of the patient's serum.

$\uparrow$ Very severe reaction.

\$ Leg pains worse.

$\$$ Feels wonderfully well, little pain.

$\llbracket$ Pains have returned. Not so severe.

sign. The blood showed a strongly positive Wassermann reaction. The spinal fluid showed a marked increase in the globulin content, 10 cells to the cubic millimeter, and a Wassermann reaction positive with 0.5 c.c. of the fluid.

Summary of Treatment.-This patient was under our observation for ten months, during which time he received six intravenous injections of salvarsan or neosalvarsan (a total equivalent to $2.65 \mathrm{gm}$. of salvarsan) and six intraspinous injections. In addition to this he received intramuscular injections of mercury salicylate with regularity.

Results and Present Condition.-Symptomatically the patient showed improvement in that the lightning pains abated temporarily. Later they became trouble- 
some again. The spinal fluid findings are interesting in that after five intraspinal injections they disappeared entirely, although the blood still remained positive. His last combined treatment was in January, 1915. In April, 1915, he wrote us the following: "I have the pains some, but less severe. My head is clear. I go sometimes a week without a sign of a pain . . . sleep well, which certainly goes to show that either one of the treatments" [intraspinal or mercury] "or the combination of the two has not been without result." In July, 1915, seven months after his last treatment, we are informed that the patient died of an acute nephritis following a severe, widespread ivy poisoning.

CASE 8.-(Table 8.) L. B. D. Advanced tabes. Male, aged 40. Married. First intraspinal treatment Nov. 11, 1914. Infected with syphilis twelve years previously. There were no secondary manifestations, so that nothing but local treatment was ever given. The spinal cord symptoms had been present for a

\section{Table 8.-(Case 8.) Advanced Tabes}

L. B. D., aged 40. Advanced tabes dorsalis. Symptoms of several years' duration. Syphilis admitted. Result: slight improvement.

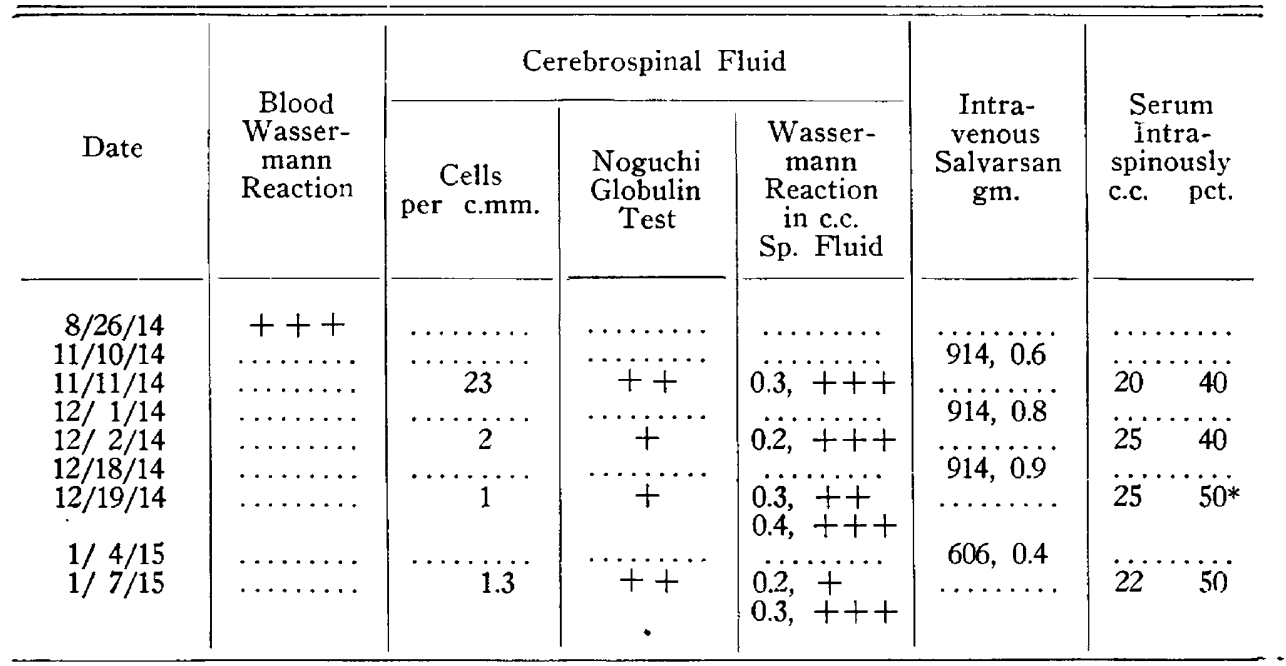

* Walks better.

number of years. He had lost much weight. His color was yellowish. $\mathrm{He}$ was distinctly emaciated and anemic. The pupils were unequal in size and did not react to light. The knee and ankle jerks were exaggerated. There was a marked ataxia. The blood showed a strongly positive Wassermann reaction. The spinal fluid showed a marked increase in globulin, 23 cells per cubic millimeter, and a Wassermann reaction which was positive when 0.3 c.c. of the fluid was tused. We were inclined to expect little, if any, improvement in this case in the light of the low cell count combined with the symptoms of rapid degeneration.

Summary of Treatment.-He received four intravenous injections of salvarsan or neosalvarsan (a total equivalent of $1.92 \mathrm{gm}$. of salvarsan) in a period of two months. This was preceded by two months of intensive mercurial injections.

Results and Present Condition.-The present condition is unchanged. The cell count in the spinal fluid fell from 23 to 1.3 per cubic millimeter, while the globulin content and the Wassermann reaction showed no diminution. 
CASE 9.-(Table 9.) A. J. K. Moderately advanced tabes. Male, aged 31. We had seen this patient in consultation in November, 1911. At that time he gave a history of having been infected six years previously and of "taking pills" for three years, almost constantly. He then had a sensation of a band around the waist and numbness in the hands and feet. Even at that time signs of moderately advanced tabes were definite and unmistakable. The blood Wassermann reaction was strongly positive. On account of the then prevalent distrust of salvarsan in neurological conditions, vigorous mercurial treatment was employed exclusively. With this he grew rapidly worse and had a partial paraplegia. When seen again in Jantary, 1914, he had been having daily mercury injections for six months and a dose of neosalvarsan intramuscularly. $\mathrm{He}$ was up and about and felt fairly well. The blood Wassermann reaction was

TABle 9.-(Case 9.) Moderately Advanced Tabes

A. J. K., aged 31. Moderately advanced tabes dorsalis. Duration: over three years. Syphilis admitted. Result: slight improvement.

\begin{tabular}{|c|c|c|c|c|c|c|}
\hline \multirow[b]{2}{*}{ Date } & \multirow{2}{*}{$\begin{array}{l}\text { Wasser- } \\
\text { Blood } \\
\text { mann } \\
\text { Reaction }\end{array}$} & \multicolumn{3}{|c|}{ Cerebrospinal Fluid } & \multirow{2}{*}{$\begin{array}{l}\text { Intra- } \\
\text { venous } \\
\text { Salvarsan } \\
\text { gm. }\end{array}$} & \multirow{2}{*}{$\begin{array}{l}\text { Serum } \\
\text { Intra- } \\
\text { spinously } \\
\text { c.c. pct. }\end{array}$} \\
\hline & & $\begin{array}{c}\text { Cells } \\
\text { per c.mm. }\end{array}$ & $\begin{array}{l}\text { Noguchi } \\
\text { Globulin } \\
\text { Test }\end{array}$ & $\begin{array}{l}\text { Wasser- } \\
\text { mann } \\
\text { Reaction } \\
\text { in c.c. } \\
\text { Sp. Fluid }\end{array}$ & & \\
\hline $11 / 25 / 11$ & $t+t$ & & & 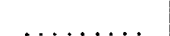 & & \\
\hline $1 / 17 / 14$ & & & …... & $\ldots \ldots$ & $\ldots \ldots \ldots$ & $\ldots \ldots$ \\
\hline $\begin{array}{l}11 / 28 / 14 \\
12 / 3 / 14\end{array}$ & $+*$ & & & & $\dddot{914}, 0.9$ & \\
\hline $12 / 4 / 14$ & & 12.5 & $+7+$ & $0.2,+++$ & oid..... & $25 \quad 40$ \\
\hline $\begin{array}{l}12 / 29 / 14 \\
12 / 30 / 14\end{array}$ & & & $\dddot{+}+\ddot{+}$ & $0.2,+++$ & $914,0.9$ & $21{ }^{\cdots}$ \\
\hline $\begin{array}{l}2 / 5 / 15 \\
2 / 6 / 15\end{array}$ & & & $\ddot{+}+\ddot{+}+$ & $0.2,+\cdots$ & $\begin{array}{c}606,0.5 \\
\ldots \ldots \ldots \ldots\end{array}$ & 25 \\
\hline $\begin{array}{l}3 / 19 / 15 \\
3 / 20 / 15\end{array}$ & $\begin{array}{l}\ldots \ldots \ldots \\
\cdots \ldots \ldots \ldots \\
\cdots\end{array}$ & $\dddot{0}$ & $\cdots+\cdots$ & $0.2, \ldots$ & $\begin{array}{c}606,0.4 \\
\ldots \ldots \ldots\end{array}$ & 30 \\
\hline $\begin{array}{l}5 / 29 / 15 \\
5 / 30 / 15\end{array}$ & & $\cdots$ & $\begin{array}{c}\text { Not } \\
\text { examined }\end{array}$ & $\begin{array}{l}0.2,+ \\
0.3,+++\end{array}$ & $\begin{array}{c}606,0.4 \\
\ldots \ldots \ldots\end{array}$ & 30 \\
\hline
\end{tabular}

* Reaction +++ when twice usual amount of patient's serum was used.

very faintly positive. We began the Swift-Ellis treatment in December, 1914. Then the pupils were small and showed no light reaction, the knee and ankle responses were abolished and there was a slight Romberg sign. Mentally the patient seemed rather slow. The spinal fluid findings were: cell count, 12.5; globulin, very heavy trace; Wassermann reaction, strongly positive with 0.2 c.c. The Lange colloidal gold test was positive.

Summary of Treatment.-This patient has been under our immediate supervision for only six months. He has had five intravenous injections, two of neosalvarsan and three of salvarsan (the total being equivalent to $2.5 \mathrm{gm}$. of salvarsan), and four serum injections.

Present Condition.-We feel that he has been under observation too short a time to permit drawing any conclusions of especial value. The spinal fluid lymphocytosis disappeared rapidly, and the patient reports that he feels stronger 
and better and that he is able to clo more work on his farm this summer than he could a year ago. The history, with the long duration of the condition, the severity of the symptoms, and the extent of involvement, pointed in advance to the need for prolonged treatment.

Case 10.-(Table 10.) J. L. S. General paresis. Male, aged 45. Married. Infected with syphilis twenty years ago. Has taken small amounts of mercury at intervals. Two years ago the patient began to have stomach trouble. He was seen in March, 1915. His speech was thick and he had the classical symptoms of an early paresis. The pupils were irregular and unequal in size. The knee and ankle jerks were exaggerated. There were no definite sensory changes. The blood showed a strongly positive Wassermann reaction. The spinal fluid showed a cell count of 25 , a very marked globulin increase and a Wassermann reaction positive in 0.2 c.c. of spinal fluid. The patient had lost much weight

\section{TABLE 10.--(CASE 10.) EARLy Parfis}

J. L. S., aged 45. Married. Early paresis. Result: improvement, especially in serological findings.

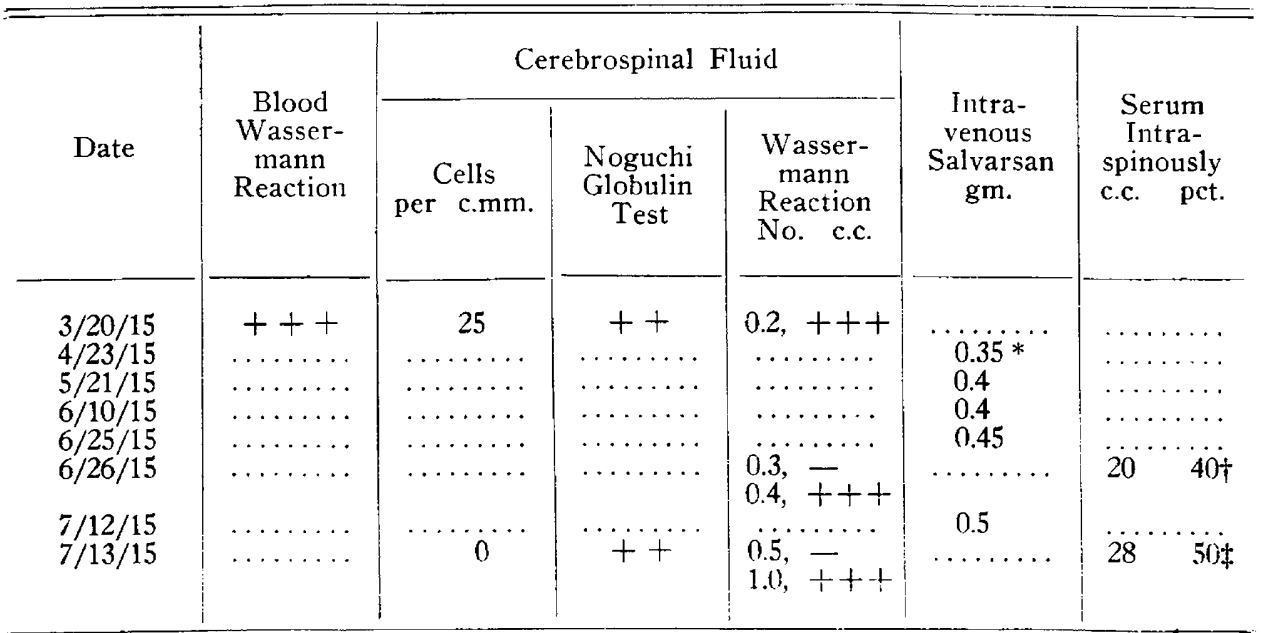

* Between 3/20 and 4/23 intensive mercury treatment. No improvement.

$\dagger$ Lange colloidal gold test typical paretic curve.

+ange much less marked.

and was running down rapidly. Between April, 1915, and July, 1915, he has received five intravenous injections of salvarsan (a total of $2.1 \mathrm{gm}$.) and two intraspinal treatments, one of 40 per cent. and one of 50 per cent. serum. After the first three intravenous injections the patient showed very little change in his condition. In fact, his difficulty in speaking and writing became worse. The spinal fluid withdrawn after the three intravenous injections showed very little improvement. Immediately after the first intraspinal treatment the patient was mentally much worse. He slurred in his speech pitifully and was almost incapable of looking after himself. This condition cleared up and about two weeks later the speech was distinctly clearer. The patient concentrated better. A spinal fluid examined at this time (July 13, 1915) showed no cells, a positive globulin, a Wassermann reaction negative in 0.5 c.c. of spinal fluid, but positive in 1.0 c.c.

While this patient has been under observation too short a time to warrant any conclusions heing drawn from the case the changes in the spinal fluid two weeks after the first intraspinal treatment are of considerable interest. 
We have given fifty-nine intraspinal injections of autosalvarsanized serum in ten cases. Further, we have given fourteen similar treatments not included in the above series, making a total of seventy-three injections. Following these injections we have seen no symptoms, temporary or permanent, which could in any way be attributed to injury to the central nervous system. We have seen no deaths, paralysis or bladder disturbances. One of our patients died of an intercurrent condition seven months after the cessation of treatment. Two of the patients have experienced no discomfort from the procedure. When gastric crises or lancinating pains exist, we have learned to expect attacks of pain, in all ways similar to the pre-existing crises. These crises usually follow the treatment after an interval of from two to four hours and they are often very severe. Their duration is usually short, and they are followed by much increased periods of freedom from pain. As the treatment continues these postoperative attacks become less and the spontaneous crises of ten disappear entirely.

It is of interest to note that those patients who have had these reactions of pain following the treatment have showed greater and more rapid improvement than those who had no discomfort from the procedure.

We have found that the increased globulin content in the spinal fluid is very resistant to treatment. A moderate increase in globulin often persists after several treatments, as in Cases 8 and 9, where only a very slight decrease in globulin has occurred after three treatments. The pleocytosis disappears rapidly. In Case 1 lymphocytosis of 550 per cubic millimeter came within normal limits after six intravenous and four intraspinal injections. Cell counts of 1.50 or below usually diminish to normal limits after from one to three treatments. We have found that the Wassermann reaction in the spinal fluid is the most obdurate of the laboratory findings. The reaction often persists in the larger doses of spinal fluid, long after the other laboratory findings have come within the normal limits.

The changes in the physical findings which we have noted under the intraspinal treatment have been a partial or complete disappearance of disturbances of sensation, lessening or disappearance of ataxia and a marked increase in weight and strength. In no case, so far observed, have we seen absent deep reflexes return, nor have we seen any change in the pupillary reactions.

The abatement or disappearance of symptoms has been most striking. In every instance in which lancinating pains were present, they have either disappeared completely or have diminished so much that they have ceased to be a real annoyance. In Case 3, gastric crises which had nearly incapacitated the patient, have disappeared. Very 
striking is the rapid improvement in the general condition, in weight, in strength and in return of the ability to carry on the daily routine of employment; in other words, the practical ending of invalidism. In some cases this improvement in the general condition can be attributed to the abolition of pain, but in others (notably Cases 3, 5 and 9) in which pain had not been a feature, this general betterment was noted. Vesical incontinence in one case has been so much less frequent that it has almost ceased to be an annoyance.

\section{RESULTS}

The results in six of these ten cases has been a symptomatic improvement so emphatic that the patient's economic efficiency has been restored. They are able to work and to enjoy life to all intents and purposes as normal individuals.

We feel that the best results will be obtained in cerebrospinal lues, and in tabes of the early or moderately advanced types. In far advanced tabes the results are in most cases dubious to say the least. Our own experience with paresis is so limited that we should have no right to make any generalization. It seems probable to us, however, that very little can be done to improve permanently a paresis once it is well established.

In concluding we feel that we can state fairly that the Swift-Ellis method is safe when the original technic is followed out to the letter. The claim of the originators that it is a valuable adjunct to the treatment of syphilitic involvement of the central nervous system is sustained as far as tabes dorsalis and cerebrospinal syphilis are concerned. It is a method which is not essential in all cases, but which applied carefully and controlled intelligently will bring about definite amelioration in symptoms and in laboratory signs where other accepted modes of attack have failed.

Rose Building. 